\title{
Glycinergic and GABAergic Synaptic Activity Differentially Regulate Motoneuron Survival and Skeletal Muscle Innervation
}

\author{
Glen B. Banks, ${ }^{1}$ Refik Kanjhan, ${ }^{1}$ Stefan Wiese, ${ }^{3}$ Matthias Kneussel, ${ }^{2}$ Loke M. Wong, ${ }^{1}$ Gregory 0’Sullivan, ${ }^{2}$ \\ Michael Sendtner, ${ }^{3}$ Mark C. Bellingham, ${ }^{1}$ Heinrich Betz, ${ }^{2}$ and Peter G. Noakes ${ }^{1}$ \\ ${ }^{1}$ School of Biomedical Sciences, University of Queensland, St. Lucia, 4072 Queensland, Australia, ${ }^{2}$ Department of Neurochemistry, Max Planck Institute for \\ Brain Research, D-60528 Frankfurt/Main, Germany, and ${ }^{3}$ Institute of Clinical Neurobiology, University of Wuerzburg, D-97080 Wuerzburg, Germany
}

\begin{abstract}
GABAergic and glycinergic synaptic transmission is proposed to promote the maturation and refinement of the developing CNS. Here we provide morphological and functional evidence that glycinergic and GABAergic synapses control motoneuron development in a regionspecific manner during programmed cell death. In gephyrin-deficient mice that lack all postsynaptic glycine receptor and some $\mathrm{GABA}_{\mathrm{A}}$ receptor clusters, there was increased spontaneous respiratory motor activity, reduced respiratory motoneuron survival, and decreased innervation of the diaphragm. In contrast, limb-innervating motoneurons showed decreased spontaneous activity, increased survival, and increased innervation of their target muscles. Both GABA and glycine increased limb-innervating motoneuron activity and decreased respiratory motoneuron activity in wild-type mice, but only glycine responses were abolished in gephyrin-deficient mice. Our results provide genetic evidence that the development of glycinergic and GABAergic synaptic inputs onto motoneurons plays an important role in the survival, axonal branching, and spontaneous activity of motoneurons in developing mammalian embryos.
\end{abstract}

Key words: motor neuron; synapse formation; cell death; GABA; glycine; axon branching

\section{Introduction}

A central feature of nervous system development in mammalian embryos is the formation of complex neural networks, such as the neuromotor system. During embryonic development, approximately half of the motoneurons generated undergo programmed cell death (PCD) (Oppenheim, 1991). Motoneuron survival and differentiation depend on trophic factors secreted from target muscle fibers and Schwann cells surrounding motor axons (Bordet et al., 2001; Acsadi et al., 2002; Wang et al., 2002; $\mathrm{Lu}$ et al., 2003). Reductions in skeletal muscle activity improve the access of a motoneuron to target-derived trophic factors by increasing the extent to which motor axons branch and form neuromuscular synapses (Oppenheim et al., 2000b; Millecamps et al., 2001, 2002). This suggests that the neuromotor system has an intrinsic safety mechanism that gives it the capacity to alter the

Received May 9, 2004; revised Dec. 16, 2004; accepted Dec. 16, 2004.

G.B.B. held a scholarship from the University of Queensland, and G.0. holds a Marie-Curie Fellowship from the European Union. P.G.N., R.K., L.M.W., and M.C.B. are supported by Australian National Health and Medical Research Council Grant NHMRC 210256 and the Motor Neuron Disease Institute Australia. H.B. is supported by the Deutsche Forschungsgemeinschaft (Sonderforschungsbereich 628) and Fonds der Chemischen Industrie. M.K. is supported by the Deutsche Forschungsgemainschaft. We thank Lynn Tolley, Dagmar Magalei, Michaela Pfister, Graham Wise, and Mary White for technical assistance. We also thank Prof. Hermann Rohrer for critical reading of this manuscript.

Correspondence should be addressed to Dr. Peter G. Noakes, School of Biomedical Sciences, University of Queensland, St. Lucia, 4072 Queensland, Australia. E-mail: p.noakes@uq.edu.au.

G. Banks' present address: Department of Physiology and Biophysics, University of Washington, Seattle, WA 98103.

M. Kneussel's present address: Zentrum für Molekulare Neurobiologie, Universität Hamburg, Falkenried 94, D-20252 Hamburg, Germany.

D01:10.1523/JNEUROSCI.1786-04.2005

Copyright $\odot 2005$ Society for Neuroscience $\quad$ 0270-6474/05/251249-11\$15.00/0 extent of its muscle innervation, to provide sufficient skeletal muscle contraction to sustain the life of a newborn.

Synaptic activity within the CNS is also essential for motoneuron survival (Verhage et al., 2000; Herroma et al., 2003). Recent studies suggest that GABAergic and glycinergic synaptic activity, which switches from producing postsynaptic excitation to inhibition during late embryonic and early postnatal stages, may be essential for the maturation and refinement of developing neural networks (Kriegstein and Owens, 2001; Ben-Ari, 2002; Owens and Kriegstein, 2002). Therefore, glycinergic and GABAergic synapse function may also control motoneuron development in mammalian embryos. Here, we examine whether disruption of glycinergic and GABAergic synaptic activity affects motoneuron survival and/or plasticity during PCD.

An effective way to study the effects of glycinergic and GABAergic synaptic activity on motoneuron development is the use of genetically modified mice lacking glycine and $\mathrm{GABA}_{\mathrm{A}}$ receptor clusters at synapses. A hallmark of synapse formation is the precise apposition of presynaptic terminals onto densely clustered postsynaptic receptors (Sanes et al., 1998; Sanes and Lichtman, 1999). Gephyrin is a tubulin-binding protein essential for clustering all glycine and different $\mathrm{GABA}_{\mathrm{A}}$ receptor subtypes in the postsynaptic membrane of central neurons (Schmitt et al., 1987; Prior et al., 1992; Kirsch and Betz, 1993; Essrich et al., 1998; Feng et al., 1998; Kneussel et al., 1999, 2001; Allison et al., 2000). A high density of these receptors in the postsynaptic membrane is vital for efficient synaptic transmission, because gephyrindeficient mice die within the first postnatal day (Feng et al., 1998; 
Kneussel et al., 1999; Grosskreutz et al., 2003). Here, the gephyrin-deficient mice were used to test whether glycinergic and GABAergic synaptic transmission affect motoneuron survival, branching, and activity by comparing morphological and functional characteristics of motoneurons in gephyrin-deficient mice with those of wild-type mice.

\section{Materials and Methods}

Mice. Gephyrin heterozygote mice bred on a 129/Ola $\times$ C57BL/6 defined background were time mated. The day a vaginal plug was observed was classified as embryonic day 0.5 (E0.5). Pregnant mothers were killed via cervical dislocation. Embryos were immediately placed on ice-cold $0.1 \mathrm{M}$ PBS, pH 7.4, and decapitated before microdissection. Embryos were later genotyped by a DNA tail assay as described previously (Feng et al., 1998). Only wild-type $(+/+)$ and gephyrin-deficient $(-/-)$ mice were used in morphological studies. For functional studies, both wild-type and gephyrin heterozygote $(+/-)$ mutants (i.e., one gephyrin allele inactivated) animals were considered as "wild-type control," because both wild-type and heterozygote newborn mice show no differences in the formation of synaptic glycine receptor and $\mathrm{GABA}_{\mathrm{A}}$ receptor clusters at synapses and are phenotypically indistinguishable from wild-type littermates (Feng et al., 1998; Kneussel et al., 1999; Levi et al., 2004). These wild-type controls were compared with gephyrin-deficient animals (Feng et al., 1998). The animal care and ethics committees of our institutions approved all described procedures and experiments.

Motoneuron counts and morphometric analyses. Motoneuron numbers were quantified using previously established methods (Clarke and Oppenheim, 1995; Banks et al., 2001). Serial 6- to 12- $\mu$ m-thick paraffin sections obtained from brainstem and spinal cord were stained using thionin in $1 \%(\mathrm{v} / \mathrm{v})$ acetic acid buffer solution. The starting and finishing positions of the lateral motor columns (LMCs) in the spinal cord were found by examining LMC thickening, presence of dorsal root ganglia (cervical 3-5 for phrenic, cervical 6 to thoracic 1 for brachial, and lumbar 1-5 for lumbar), and morphology of the vertebrae. Motoneurons were identified and counted in every fifth (cranial) or 10th (LMC) section as described previously (Clarke and Oppenheim, 1995; Banks et al., 2001, 2003). Spinal cord volume and nuclear area calculations were obtained using previously established methods (Banks et al., 2001). The genotypes were not made available to the researcher conducting these analyses (G.B.B., P.G.N.) until they were complete. Motoneuron numbers, spinal cord volume, and nuclear areas were compared using an unpaired Student's $t$ test.

Quantitation of motoneuron branching. Embryonic diaphragm and gluteus maximus muscles were processed for whole-mount immunohistochemistry as described previously (Gautam et al., 1995; Banks et al., 2001, 2003). Motor axon branches were localized with a neurofilament (1:200; Sigma, St. Louis, MO) and synaptophysin (1:50; Dako, High Wycombe, UK) primary rabbit antibody mixture and probed for with an FITC-conjugated rabbit secondary antibody (1:400; Chemicon, Boronia, Australia). Postsynaptic acetylcholine receptors (AChRs) were localized using rhodamine-conjugated $\alpha$-bungarotoxin (1:400; Molecular Probes, Eugene, OR). The most ventral $1.2 \mathrm{~mm}$ of the left hemi-diaphragm at E18.5 and the ventral $500 \mu \mathrm{m}$ portion at E16, plus the proximal muscle nerve entry point of the gluteus maximus muscle, were used for quantifying axonal branching and neuromuscular synapse number. The branch extension for the main muscle nerve trunk, the number of branches exiting this nerve trunk, and the number of peripheral branch bifurcations were quantified, as detailed previously (Banks et al., 2001, 2003). The number of neuromuscular synapses, defined as the number of AChR clusters that colocalized with neurofilament/synaptophysin immunostaining, were also counted. All of these measurements were collected and compared among gephyrin-deficient and wild-type mice, using Prism 3.0 software (GraphPad Software, San Diego, CA), as described previously (Banks et al., 2001, 2003). All immunostained muscles were viewed using a Bio-Rad (Hercules, CA) MRC 600 scanning confocal microscope. A Z-series of each muscle was collected and projected into a single image using NIH ImageJ image software (available from http:// rsb.info.nih.gov/ij/). Individual images were placed into multi-panel figures using Adobe Photoshop 7 (Adobe Systems, San Jose, CA).

Hypoglossal and lumbar nerve activity recordings. Brainstem-whole spinal cord preparations (Suzue, 1984; Smith and Feldman, 1987) from 17 gephyrin-deficient and 19 control (wild-type or gephyrin heterozygote mutant) mice of either sex at postnatal day 0 (P0) to P1.5 were used for in vitro nerve recording experiments. Animals were anesthetized by hypothermia for 3-5 min, before decerebration rostral to the pons and removal of the cerebellum. The intact brainstem and entire spinal cord were removed from the surrounding tissue by laminectomy and sectioning nerve rootlets while immersed in Ringer's solution containing the following (in mM): $128 \mathrm{NaCl}, 3 \mathrm{KCl}, 21 \mathrm{NaHCO}_{3}, 0.5 \mathrm{NaH}_{2} \mathrm{PO}_{4} \cdot \mathrm{H}_{2} \mathrm{O}, 1$ $\mathrm{MgCl}_{2}, 1.5 \mathrm{CaCl}_{2}$, and 30 D-glucose, $\mathrm{pH} 7.4$ (continuously bubbled with $95 \% \mathrm{O}_{2} / 5 \% \mathrm{CO}_{2}$ ). The preparation was pinned ventral surface up in a 35 $\mathrm{ml}$ bath and continuously perfused with the same solution at $24-26^{\circ} \mathrm{C}$ at a flow rate of $12-15 \mathrm{ml} / \mathrm{min}$ using a peristaltic pump (Minipuls 3; Gilson, Villiers le Bel, France). Suction electrode recordings were made from hypoglossal (XII) nerve rootlets and L5 ventral nerve roots. The nerve signals were AC amplified (2000-10,000 X), rectified, low-pass filtered at $1 \mathrm{kHz}$, integrated (time constant, $50 \mathrm{~ms}$ ), displayed on a storage oscilloscope, and stored on a personal computer using an digitizer interface and software (DigiData 1200A and PClamp7; Axon Instruments, Union City, $\mathrm{CA}$ ) at a sampling rate of $2 \mathrm{kHz}$. Analysis of nerve activity was performed off-line using Clampfit 9.0 software (Axon Instruments). Bursts of integrated nerve activity were detected by exceeding a threshold set at more than three times the root mean square baseline noise level. Peak amplitude, half-width, $10-90 \%$ rise time, $10-90 \%$ decay time, and area of XII and L5 nerve bursts were automatically measured after visual inspection of all detected bursts to eliminate any artifactual activity. Prism 3.0 was used to calculate the mean values of all measurements $(20-230$ bursts per animal) and for all statistical analyses. The mean nerve activity (charge per minute) was calculated by dividing the total burst area for all bursts by the recording duration (in minutes) for each preparation. GABA or glycine (100 $\mu \mathrm{M}$ each; Sigma, Sydney, Australia) were dissolved in the perfusing fluid at the stated concentrations and applied continuously. GABA or glycine effects were measured by comparison of the mean control parameters for 10-20 min of nerve activity before drug application and mean parameters for the period of drug application (minimum of 8 min of nerve activity). Data are presented as means \pm SEM except when indicated, and significance was accepted at the $p<0.05$ level using two-tailed unpaired Student's $t$ test or two-way ANOVA tests when specified.

Motoneuron cultures. Cultures of lumbar spinal motoneurons from E14 mice were prepared by an immunopanning technique as described previously (Hughes et al., 1993). The motoneurons were plated at a density of 2000 cells $/ \mathrm{cm}^{2}$ in four-well culture dishes precoated with polyL-ornithine (Sigma-Aldrich, Munich, Germany) and laminin (gift from Rupert Timpl, Max Planck Institute, Munich Germany) as described previously (Arakawa et al., 1990). Cells were grown with $10 \%$ horse serum in Neurobasal medium supplemented with B27 and $500 \mathrm{~mm}$ glutamax I (Invitrogen, Eggensten, Germany) at $37^{\circ} \mathrm{C}$ in a humidified atmosphere with $5 \% \mathrm{CO}_{2}$. After $1 \mathrm{~h}$, the Neurobasal medium was supplemented with one of the following neurotrophic factors at a concentration of $1 \mathrm{ng} / \mathrm{ml}$ : glia-derived neurotrophic factor (GDNF) (PreProtech, Frankfurt, Germany); brain-derived neurotrophic factor (BDNF) (Amgen, Thousand Oaks, CA); and ciliary neurotrophic factor (CNTF) (rat and human expressed and purified as described by Masiakowski et al., 1991).

The initial cell number per well was determined $3 \mathrm{~h}$ after plating by phase-contrast microscopy (magnification, $125 \times$ ). Surviving neurons were counted in the same fields at different time points for up to $5 \mathrm{~d}$ in culture, and the results are presented as the percentage of the originally plated cell number. After $5 \mathrm{~d}$ in culture, the axonal processes of the motoneurons were stained with anti-P-Tau (Sigma-Aldrich, Munich, Germany) and visualized with a goat anti-rabbit Cy2 antibody $(10 \mathrm{mg} /$ $\mathrm{ml}$; Biomol, Hamburg, Germany) as described previously (Metzger et al., 1998).

Electron microscopy. Gluteus maximus muscles were removed from the hindlimbs of P0 mice and fixed in 3\% (w/v) glutaraldehyde in $0.1 \mathrm{M}$ 


\begin{tabular}{|c|c|c|c|}
\hline & $+/+$ & $-1-$ & \% Change \\
\hline \multicolumn{4}{|c|}{ (V) Trigeminal } \\
\hline E15.5 & $2283 \pm 176(4)$ & $1710 \pm 162(4)^{*}$ & -15 \\
\hline E18.5 & $883 \pm 29(4)$ & $659 \pm 97(3)^{* *}$ & -25 \\
\hline \multicolumn{4}{|l|}{ (VII) Facial } \\
\hline E15.5 & $6904 \pm 630(3)$ & $7217 \pm 640(3)$ & +3 \\
\hline E18.5 & $3067 \pm 292(5)$ & $2234 \pm 138(4)^{*}$ & -27 \\
\hline \multicolumn{4}{|c|}{ (XII) Hypoglossal } \\
\hline E15.5 & $4045 \pm 523(4)$ & $3181 \pm 353(4)^{*}$ & -21 \\
\hline E18.5 & $1279 \pm 131$ & $867 \pm 120(4)^{*}$ & -32 \\
\hline \multicolumn{4}{|l|}{ Phrenic } \\
\hline E15.5 & $1125 \pm 111(3)$ & $707 \pm 95(3)^{* *}$ & -37 \\
\hline E18.5 & $653 \pm 25(3)$ & $458 \pm 53(4)^{* *}$ & -30 \\
\hline \multicolumn{4}{|l|}{ Brachial } \\
\hline E13.5 & $5235 \pm 496(3)$ & $5100 \pm 199(3)$ & -3 \\
\hline E15.5 & $2584 \pm 312(4)$ & $3294 \pm 353(4)^{*}$ & +27 \\
\hline E18.5 & $1957 \pm 267(6)$ & $2393 \pm 328(6)^{*}$ & +22 \\
\hline \multicolumn{4}{|l|}{ Lumbar } \\
\hline E16 & $2489 \pm 251(3)$ & $3084 \pm 228(3)^{*}$ & +24 \\
\hline E18.5 & $2038 \pm 107(3)$ & $2793 \pm 358(5)^{* *}$ & +37 \\
\hline
\end{tabular}

Values represent the mean $\pm S D$ number of motoneurons. Values in parentheses show the number of animals examined. ${ }^{*} p<0.05 ;{ }^{* *} p<0.01 ; t$ test.

phosphate buffer, $\mathrm{pH} 7.2$, for $12 \mathrm{~h}$ at $4^{\circ} \mathrm{C}$. Fixed muscles were washed in phosphate buffer, postfixed in $1 \%(\mathrm{w} / \mathrm{v})$ aqueous osmium tetroxide containing $1.5 \%(\mathrm{w} / \mathrm{v})$ potassium ferrocyanide (Kopriwa, 1984), stained en bloc with uranyl acetate, dehydrated through acetone into Epon resin, embedded, and polymerized at $60^{\circ} \mathrm{C}$ for $24 \mathrm{~h}$. Ultrathin sections were cut at $\sim 80 \mathrm{~nm}$, stained with Reynolds lead citrate (Reynolds, 1963), viewed, and photographed with a Hitachi (Tokyo, Japan) H600 transmission electron microscope.

\section{Results \\ Regional differences in motoneuron survival in gephyrin-deficient mice}

We examined whether the severe deficits in GABAergic and glycinergic synapse formation found in gephyrin-deficient mice affect motoneuron survival in respiratory-related motor nuclei during embryonic development. Embryonic days 15 and 18.5 were chosen to examine motoneuron survival in the hypoglossal, trigeminal, facial, and phrenic motoneurons, because it is well established that motoneuron death is well underway by E18.5 in all of these nuclei (Oppenheim et al., 2000a; Terrado et al., 2001; Banks et al., 2003; Forger et al., 2003). For facial motor nuclei, it has been reported that the motoneuron death period begins at E17.5 and ends 3-4 d later in the first postnatal week (Ashwell and Watson, 1983). The period of PCD has not been defined for the other cranial nuclei or the hypoglossal nucleus, and, because these motor nuclei only become distinct after E13.5, we chose to quantify motoneurons at E15.5 and E18.5 to test whether PCD is affected during the motoneuron PCD period. First, there were significant decreases in motoneuron number in the hypoglossal nuclei at E15.5 [21\% decrease; $p<0.03$ (Table 1)] and E18.5 [32\% decrease; $p<0.01$ (Table 1)]. Second, motoneuron numbers were significantly decreased in the trigeminal motor nuclei at E15.5 [15\% decrease; $p<0.03$ (Table 1)] and E18.5 [25\% decrease; $p<0.01$ (Table 1)]. Third, facial motoneuron numbers did not change at E15.5 (3\% increase; $p>0.58$ ), but, by E18.5, numbers were significantly decreased by $27 \%(p<0.03)$ in gephyrin-deficient mice (Table 1). Last, the number of motoneurons within cervical segments that innervate the diaphragm (Noakes et al., 1983) were reduced in gephyrin-deficient mice com- pared with wild-type mice at both E15.5 [37\% decrease; $p<0.008$ (Table 1)] and E18.5 [30\% decrease; $p<0.005$ (Table 1)]. Thus, motoneuron survival in respiratory-related motor nuclei is decreased in gephyrin-deficient mice.

GABA and glycinergic synapses are also present on spinal somatic motoneurons. We counted the number of motoneurons in the brachial and LMCs throughout the period of PCD in wildtype and gephyrin-deficient mice (E13.5-E18.5). At the initial stages of synapse formation within the CNS at E13.5, we found no changes in motoneuron number in the brachial LMC in gephyrin-deficient mice (Table 1). This indicates that the generation of somatic motoneurons and the number of early postmitotic neuroblasts undergoing PCD were not altered in gephyrindeficient mice. However, significant increases in motoneuron number were seen in the brachial LMC at E15.5 (27\% increase; $p<0.02$ ) and E18.5 [22\% increase; $p<0.03$ (Table 1)]. Similarly, we also observed significant increases in motoneuron number in the lumbar LMC at E16 [24\% increase; $p<0.05$ (Table 1)] and E18.5 [37\% increase; $p<0.01$ (Table 1)]. E16 and E18.5 represent the middle and end stages of the motoneuron PCD period for spinal motoneurons, respectively (Lance-Jones, 1982; Banks et al., 2001, 2003). Therefore, in contrast to the reduced survival of respiratory cranial motoneurons, survival of motoneurons that innervate the forelimbs and hindlimbs was increased in gephyrin-deficient mice.

\section{Motor axon branching and neuromuscular synapse formation in gephyrin-deficient mice}

Increased motoneuron survival has been found to correlate with an increase in motor axon branching and neuromuscular synapse formation (Oppenheim et al., 2000b, 2003) and vice versa (Tang and Landmesser, 1993) from the beginning of synapse formation (Dahm and Landmesser, 1988; Banks et al., 2003). We therefore examined whether the differential changes in motoneuron survival found in gephyrin-deficient mice are accompanied by respective changes in motor axon branching and neuromuscular synapse formation in respiratory (diaphragm) and limb muscles at E16 (early stages of neuromuscular synapse formation and midperiod of motoneuron PCD) and E18.5 (late stage of motoneuron PCD).

At E18.5 and E16, axonal branching and neuromuscular synapse formation in the ventral regions of the left hemi-diaphragm show little anatomical variation in wild-type mice (Banks et al., 2001, 2003). Intramuscular axonal branches extended primarily toward the lateral side of the phrenic nerve trunk in both wildtype (Fig. $1 A, E$ ) and gephyrin-deficient (Fig. $1 B, F$ ) diaphragms. However, these axon branches extended up to $40 \mu \mathrm{m}$ farther in wild-type mice (Fig. 1C) compared with gephyrin-deficient animals (Fig. $1 D$ ) at E18.5. This same trend was also apparent at earlier ages [E16 (Fig. 1, compare $G, H$ )]. We next quantified the number of axon bifurcations and neuromuscular synapses at these two ages [E18.5 and E16 (Figs. $1 E, F, 2 A, B$, respectively)]. At E18.5, both number of axon bifurcations and neuromuscular synapses were significantly decreased in gephyrin-deficient diaphragms [for bifurcations, $28 \%$ decrease, $p=0.007$ (Fig. 2C); for synapses, $21 \%$ decrease, $p=0.0383$ (Fig. 2D)]. Similarly, at E16 we also observed a lower degree of axon bifurcations and significantly fewer neuromuscular synapses in gephyrin-deficient diaphragms compared with wild-type [for bifurcations, 37\% decrease, $p=0.17$ (Fig. 2C); for synapses, $34 \%$ decrease, $p=0.0022$ (Fig. 2D)]. Therefore, the decrease in phrenic motoneuron survival correlates with a reduced innervation of the gephyrindeficient diaphragms. 

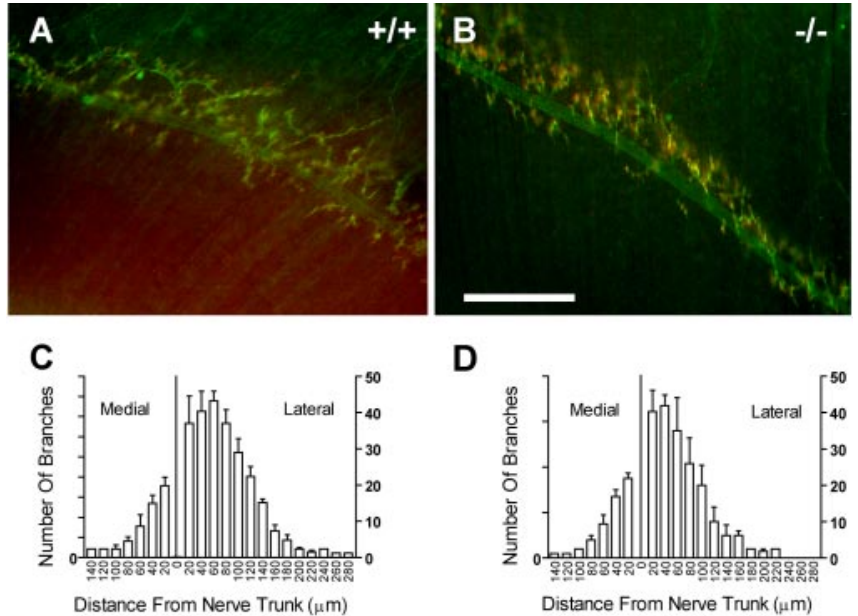

D
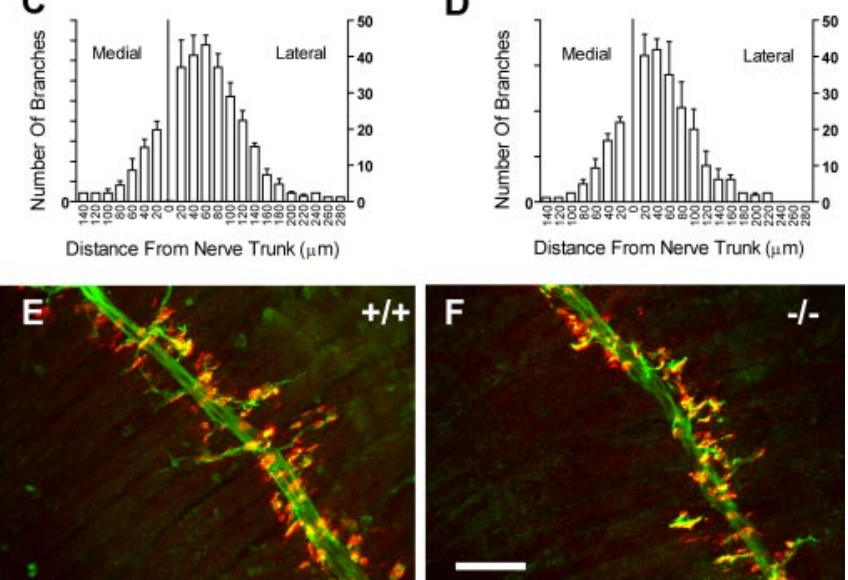

G

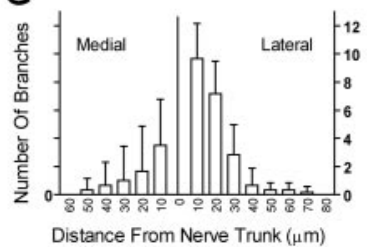

H

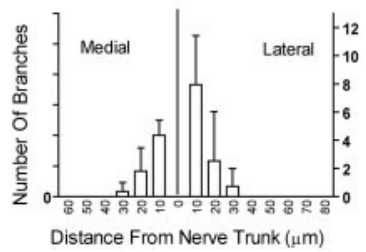

Figure 1. Lateral motor axon extension is restricted in the diaphragm in gephyrin-deficient mice. Motor axon branches (green) and acetylcholine receptor clusters (red) in the left hemidiaphragms in wild-type $(+/+)$ and gephyrin-deficient $(-/-)$ mice at E18.5 $(A, B)$ and E16 $(E, F)$ are shown. Quantification of the distance axons extending from the nerve trunk (mean \pm SEM) for wild-type $(C, E 18.5 ; G, E 16)$ and gephyrin-deficient $(D, E 18.5 ; H, E 16)$ mice taken from four litter-matched pairs is also shown. Scale bars: $A, B, 200 \mu \mathrm{m} ; E, F, 50 \mu \mathrm{m}$.

To reveal whether the increased lumbar motoneuron survival seen in gephyrin-deficient animals correlated with increases in intramuscular axonal branching and synapse formation in the hindlimb, we examined the gluteus maximus, a hindlimb muscle innervated by lumbar motoneurons at E18.5 and E16 (Fig. 3). Indeed, the number of motor axon branches and neuromuscular synapses were increased in the gephyrin-deficient muscle compared with wild type at both E18.5 and E16 (Fig. 3A-D) with the greatest change seen at E18.5 [for synapses at E18.5, 69\% increase, $p=0.05$ (Fig. 3E); for bifurcations at E18.5, 59\% increase, $p=0.0033$ (Fig. $3 F$ ); compared with synapses at E16, 20\% increase, $p=0.12$ (Fig. 3E); for bifurcations at E16, $80 \%$ increase, $p=0.0023$ (Fig. $3 F$ ) ]. Together, these results show that the regional changes in motoneuron survival observed in gephyrindeficient mice correlate with regional differences in axon branching and neuromuscular synapse number.

We also examined the morphology of neuromuscular junctions (NMJs) from diaphragm and gluteus maximus muscles in gephyrin-deficient mice at P0. This was done at both the light and electron microscopic levels. At the light microscopic level, we observed no changes in overall size of the NMJ, terminal arborizations, or the appearance of postsynaptic acetylcholine re-
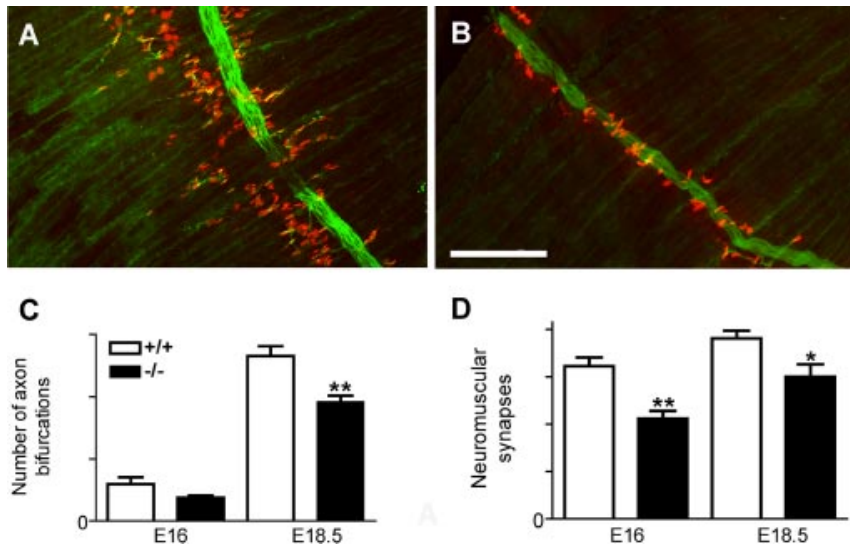

Figure 2. The number of axon branches and neuromuscular synapses is reduced in the diaphragm of gephyrin-deficient mice. Motor axon branches (green) and postsynaptic acetylcholine receptor clusters (red) in wild-type $(A,+/+)$ and gephyrin-deficient $(B,-/-)$ diaphragms at E18.5 are shown. Note that there were fewer axon bifurcations and neuromuscular synapses in the $-1-$ compared with the $+/+$. Scale bar, $100 \mu \mathrm{m}$. ( shows the total number (mean \pm SEM) of axon bifurcations in the most ventral $1.2 \mathrm{~mm}$ of the left hemi-diaphragm in wild-type (white bars) and gephyrin-deficient (black bars) mice taken from four litter-matched pairs at $E 18.5$ and E16. D shows the number (mean \pm SEM) of neuromuscular synapses in the same regions. ${ }^{*} p<0.05 ;{ }^{* *} p<0.01 ; n=4$; Student's $t$ test.
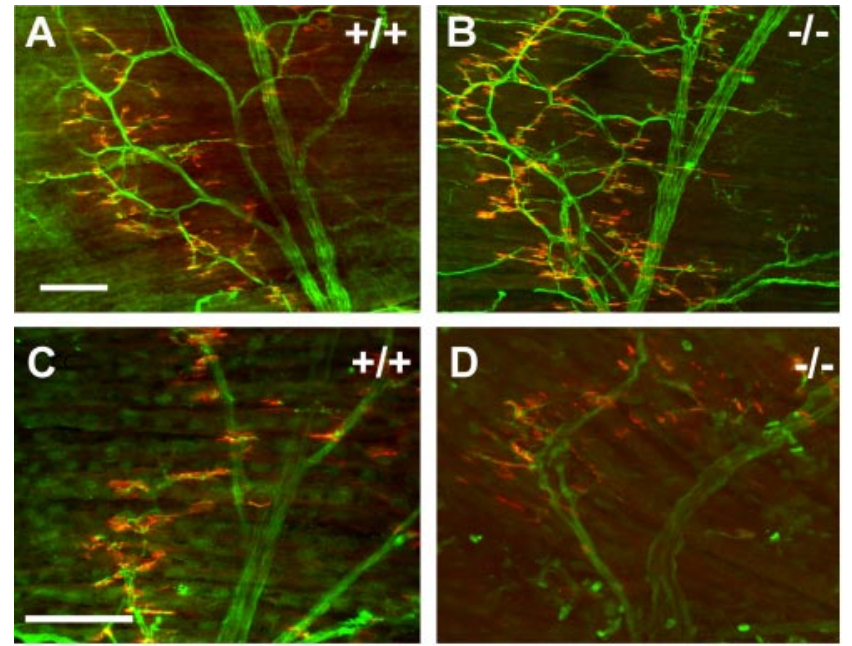

E

$\mathbf{F}$
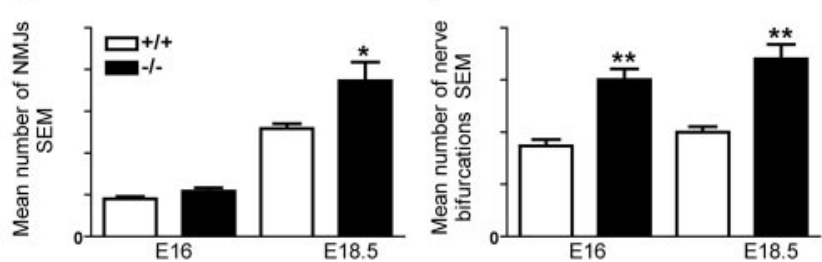

Figure 3. Increased innervation of limb muscles in gephyrin-deficient mice. Motor axon branches (green) and acetylcholine receptor clusters (red) in the gluteus maximus muscle in wild-type (A, E18.5; $C$, E16; $+/+)$ and gephyrin-deficient $(B, E 18.5 ; D, E 16 ;-/-)$ mice are shown. $E$ and $F$ show the numbers (mean \pm SEM) of gluteus maximus NMJs and branch bifurcations over the same muscle region for wild-type (white bars) and gephyrin-deficient (black bars) E18.5 and E16 mice. There were significantly more neuromuscular synapses and branch bifurcations in the gluteus maximus muscles from gephyrin-deficient mice compared with wild-type controls. ${ }^{*} p<0.05$; ${ }^{* *} p<0.01 ; n=5$; Student's $t$ test. Scale bars: $A, B, 100 \mu \mathrm{m} ; C, D, 50 \mu \mathrm{m}$.

ceptor clusters (Fig. 4, top panels). These observations were supported at the electron microscopic level, in which we saw no obvious change in the ultrastructural appearance of motor nerve terminals, synaptic cleft distance, and synaptic basal lamina or- 

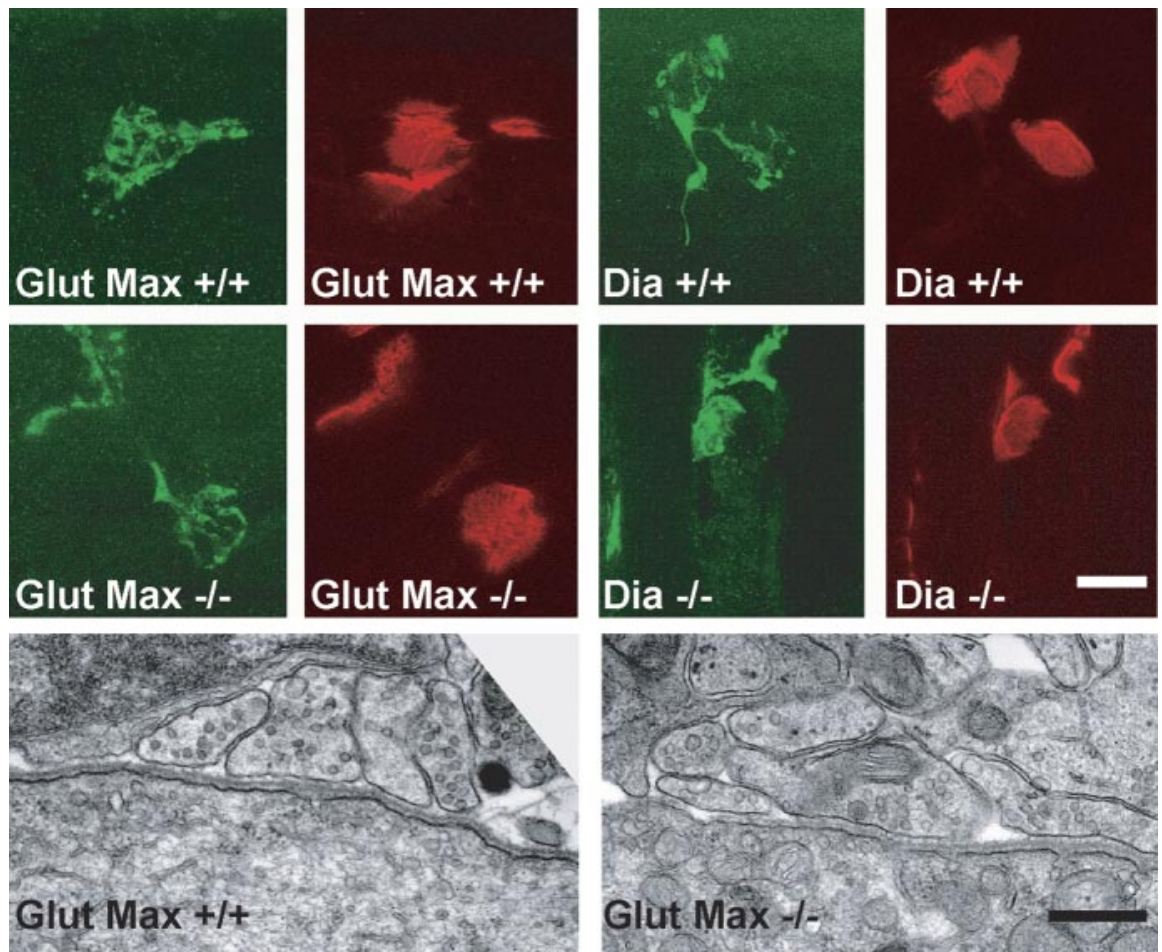

Figure 4. The development of NMJs is not changed in gephyrin-deficient mice at PO. The top two rows show confocal images of NMJs from wild-type $(+/+)$ and gephyrin-deficient $(-/-)$ mice that have been stained for axon nerve terminals with anti-neurofilament plus anti-synaptophysin (green) and for acetylcholine receptors with $\alpha$-bungarotoxin (red). NMJs from wildtype and gephyrin-deficient diaphragms (Dia $+/+$ and Dia $-/-$, respectively) and from wild-type and gephyrin-deficient gluteus maximus muscles (Glut Max $+/+$ and Glut Max - /-, respectively) are shown. Scale bar, $20 \mu \mathrm{m}$. The bottom row shows electron micrographs of NMJs from wild-type $(+/+)$ and gephyrin-deficient $(-/-)$ gluteus maximus muscle at $P 0$. There were no ultrastructural differences in the NMJs from gephyrin-deficient mice compared with wild-type littermate controls. Scale bar, $500 \mathrm{~nm}$.

ganization (Fig. 4, bottom panels). In conclusion, we observed no changes in gross morphology of neuromuscular synapses in gephyrin-deficient mice compared with littermate controls.

\section{Regional variation in spontaneous motor activity in gephyrin-deficient mice}

The regional differences in motoneuron survival and branching found with gephyrin deficiency could, in part, be attributable to differences in the neural activity of respiratory and nonrespiratory motoneuron pools (Oppenheim and Nunez, 1982; Oppenheim et al., 2000b). To test whether gephyrin deficiency might alter motoneuron PCD and peripheral branching by changing the activity of respiratory and spinal motoneurons, we recorded spontaneous bursts of activity from both hypoglossal (XII) and lumbar (L5) nerves in an in vitro brainstem-whole spinal cord preparation isolated from postnatal day $0-1.5$ mice. At $\mathrm{P} 0-\mathrm{P} 1.5$, lumbar motoneurons are toward the end of the cell death period, and hypoglossal motoneuron death is in its later phase (Oppenheim et al., 2000a; Terrado et al., 2001; Banks et al., 2003; Forger et al., 2003). Furthermore, our results above show that significant changes in XII and L5 motoneuron numbers, muscle nerve branching, and synapse numbers in gephyrin-deficient mice have occurred from E15 up to E18 (Table 1). Hence, P0-P1.5 is a time point at which functional changes in motor activity correlated with motoneuron PCD should be fully detectable. Indeed, in both nerves, spontaneous activities differed significantly between control (wild type and heterozygote) and gephyrin-deficient mice (Fig. 5A). The mean burst frequency of lumbar nerve activ- ity was decreased in gephyrin-deficient mice $[76 \%$ decrease; $p=0.013$ (Fig. $5 B$; Table 2)]. In contrast, the frequency of hypoglossal nerve burst activity was significantly increased in the knock-out animals [127\% increase; $p=0.035$ (Fig. 5B; Table $2)]$. A similar change was observed in the mean nerve activities. Lumbar activity was significantly reduced in gephyrin-deficient mice compared with wild-type mice [76\% decrease; $p=0.02$ (Fig. 5C; Table 2)], whereas the mean hypoglossal activity was significantly increased [369\% increase; $p=0.003$ (Fig. 5C; Table 2)]. These changes in motoneuron pool activity were primarily attributable to altered burst frequencies, because the mean parameters for burst shape measured (including peak amplitude, half-width, $10-90 \%$ rise time, $10-$ $90 \%$ decay time, and area) from hypoglossal and lumbar nerves did not significantly differ between gephyrin-deficient and wild-type mice (Table 2). Thus, increases in spontaneous activity of respiratory motoneurons coincide with decreases in motoneuron numbers, peripheral branching, and neuromuscular synapse formation, whereas the reciprocal effect was seen with hindlimb somatic motoneurons.

\section{Regional variation in glycine/GABA effects on motor activity in wild-type and gephyrin-deficient mice}

Because the absence of gephyrin disrupts all postsynaptic glycine receptor clusters and most $\mathrm{GABA}_{\mathrm{A}}$ receptor clusters, but possibly not $\mathrm{GABA}_{\mathrm{B}}$ or $\mathrm{GABA}_{\mathrm{C}}$ receptors, it was important to determine the relative contributions of GABA and glycine receptor activation to the functional changes in motoneuron activity for the two motoneuron pools studied. If the observed regional differences in spontaneous nerve burst frequency seen in gephyrin-deficient versus wild-type mice are attributable to defective clustering of glycine and $\mathrm{GABA}_{\mathrm{A}}$ receptors, then application of the natural ligands glycine or GABA to brainstem-spinal cord preparations from wild-type mice should also produce regional motor effects, which should be opposite to the changes seen in spontaneous motor activity seen in gephyrin-deficient mice. We therefore bath applied glycine $(100 \mu \mathrm{M})$ or GABA $(100 \mu \mathrm{M})$ to preparations from wild-type $(n=$ $10)$ and gephyrin-deficient $(n=9)$ mice for $8-10$ min and compared mean L5 or XII nerve burst frequency, amplitude, and charge before and during drug application. A two-way ANOVA of changes in burst frequency for each ligand, using genotype and nerve as the grouping variables, found significant differences between responses of the two motor nerves that were significantly influenced by genotype (Fig. 5D,E; Table 3 ). In contrast, no significant effects of either glycine or GABA on mean burst amplitude or charge were seen, regardless of nerve recorded or animal genotype (two-way ANOVA) (Table 3). Together, these results suggest that glycine and GABA produce their affects primarily on premotor circuits.

In wild-type mice, both glycine and GABA produced an increase in L5 nerve burst frequency, whereas both ligands caused a decrease in XII burst frequency (Fig. 5D,E; Table 3). These results 
for glycine and GABA receptor activation are consistent with our spontaneous data, suggesting that glycinergic and GABAergic receptors are excitatory for L5 motor activity and inhibitory for XII motor activity at this age (Fig. 5B-E). The effects of glycine on burst frequency of both motor nerves were abolished in gephyrindeficient mice (Fig. 5E). In contrast, the effect of GABA on nerve burst frequency was enhanced in gephyrin-deficient mice (Fig. 5D). Although we cannot rule out the possibility that $\mathrm{GABA}_{\mathrm{A}}$ effects might be masked by responses attributable to other GABA receptor types, such as $\mathrm{GABA}_{\mathrm{B}}$ and $\mathrm{GABA}_{\mathrm{C}}$, which are also expressed by motoneurons (Rekling et al., 2000), our simplest interpretation of these results is that $\mathrm{GABA}_{\mathrm{A}}$ receptor activation is upregulated in newborn gephyrin-deficient mice.

\section{Motoneuron and skeletal muscle differentiation are unchanged in gephyrin-deficient mice}

To test whether the absence of gephyrin could affect motoneuron development and differentiation, we analyzed various aspects of motoneuron morphology in gephyrin-deficient mice. Consistent with observations by Feng et al. (1998), we found no significant changes in spinal cord appearance or volume (spinal cord volume: $+/+, 1.2 \pm 0.02 \mathrm{~mm}^{2}$, mean \pm SEM; $-/-, 1.1 \pm 0.05 \mathrm{~mm}^{2}$, mean \pm SEM; $n=3$ ), nor did we see any alterations in the positions of the LMCs between wildtype and gephyrin-deficient mice (Fig. $6 A)$. In addition, there were no changes in cranial motor nuclei appearance (data not shown). Motoneuron morphology was assessed by measuring motoneuron nuclear area, an indirect measurement of cell body size (Oppenheim et al., 1982). Again, we found no significant difference in the nuclear areas for spinal or cranial motoneurons between genotypes at E15.5 and E18.5 (Fig. 6B). Thus, gephyrin deletion does not appear to affect the morphological development or maturation of motoneurons during the period of PCD.

Next, we used highly enriched embryonic motoneuron cultures to test whether the absence of gephyrin affects motoneuron morphological differentiation and survival under controlled conditions. We cultured lumbar motoneurons from gephyrin-deficient and wild-type mice in the presence or absence of the known motoneuron trophic factors BDNF, CNTF, or GDNF (Sendtner et al., 2000). Approximately $10 \%$ of either wild-type and gephyrin-deficient motoneurons survived after $5 \mathrm{~d}$ in culture in the absence of trophic factors (Fig. 7 ). In the presence of BDNF, CNTF, or GDNF, $\sim 50 \%$ of the originally plated wild-type and gephyrin-deficient motoneurons were maintained (Fig. 7). Furthermore, when we stained motor axon branches with anti-P-Tau, we saw no difference in axonal Two-way ANOVA; $p<0.05$.

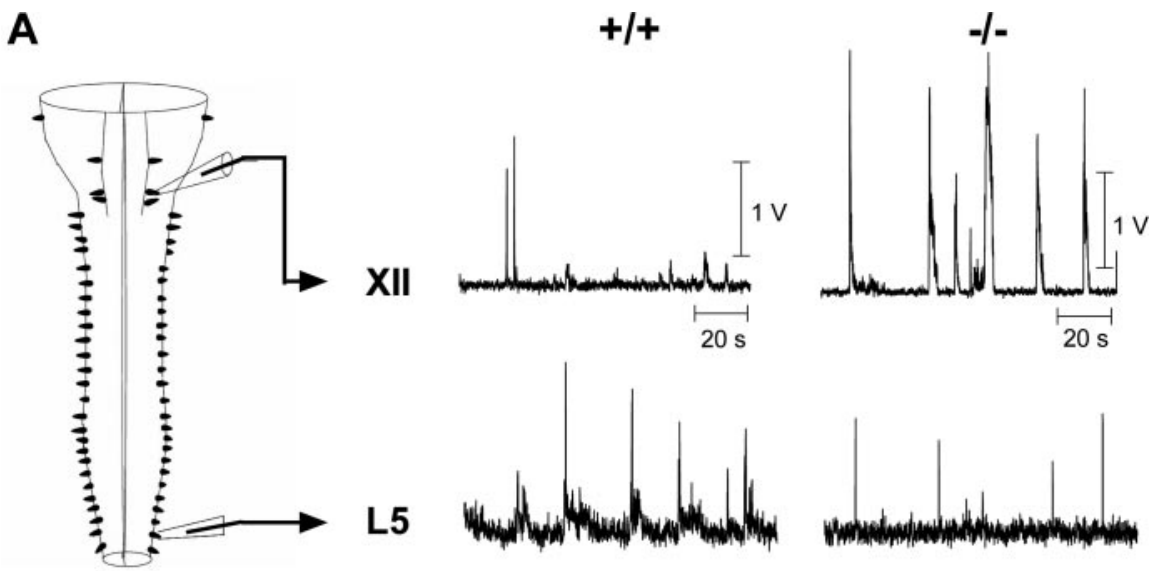

B
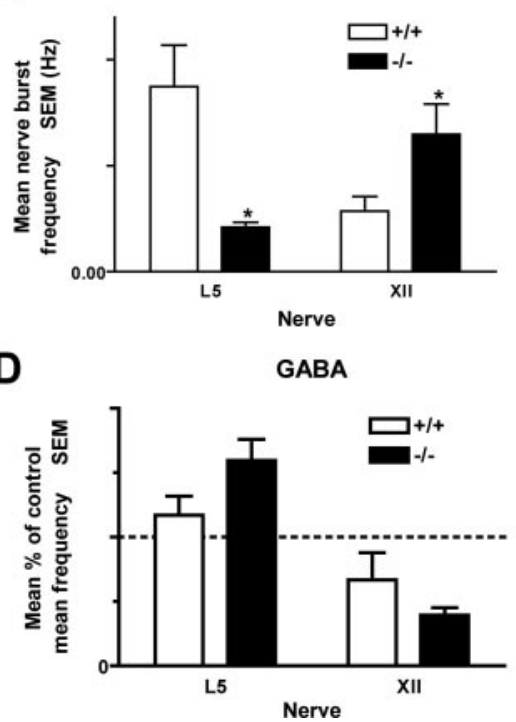

C

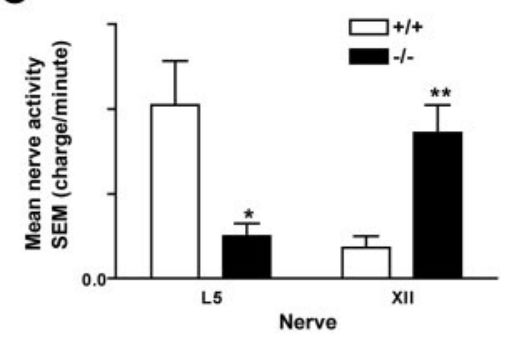

E

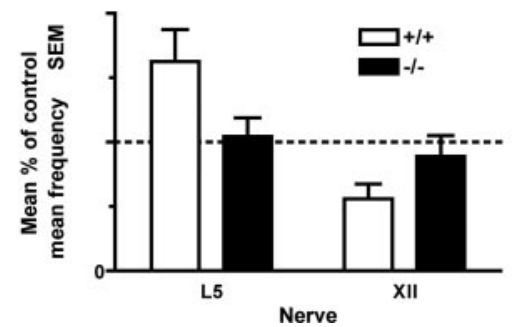

Figure 5. Regional differences in spontaneous and drug-induced motor activity in wild-type $(+/+)$ and gephyrin-deficient $(-/-)$ mice. $A$, An example of the differences in nerve burst activity from hypoglossal (XII) and lumbar (L5) ventral rootlets recorded from $+/+$ and $-/-$ brainstem-whole spinal cords. $B$, Mean nerve burst frequency for $\mathrm{L} 5(+/+, n=9 ;-/-, n=$ 7) and hypoglossal $(+/+, n=6 ;-/-n=4)$ nerve recordings showing a significant decrease in lumbar nerve burst frequency dan increase in hypoglossal nerve burst frequency. $C$, Mean nerve activity per minute (calculated as total nerve burst charge per minute) for lumbar $(+/+, n=9 ;-/-, n=7)$ and hypoglossal $(+/+, n=6 ;-/-, n=4)$ nerve recordings, showing a significant decrease in lumbar mean nerve activity and an increase in hypoglossal nerve activity. ${ }^{*} p<0.05$; ${ }^{* *} p<0.01$; Student's $+/+$ and $-/-$ mice. Mean burst frequency during drug application is shown as a percentage of burst frequency for $10-20$ min before drug application (indicated by dashed line and referred to in text as "control"). D, GABA (100 $\mu \mathrm{m}$ ) application increases (black bars). Two-way ANOVA; $p<0.05$. E, Glycine (100 $\mu \mathrm{m})$ application also increases mean lumbar burst frequency and decreases hypoglossal nerve burst frequency in $+/+$ mice (white bars); these effects are abolished in $-I-$ mice (black bars).

extension of gephyrin-deficient motoneurons compared with wild-type motoneurons in the absence of trophic factors (axon length: $+/+, 760 \pm 299.8 \mu \mathrm{m}$, mean $\pm \mathrm{SD} ;-/-, 808 \pm 310.2$ $\mu \mathrm{m}$, mean $\pm \mathrm{SD} ; n=100$ )

Next, we examined the morphology of skeletal muscle in transverse sections at E18.5 and observed no difference in skeletal muscle morphology and organization (Fig. 6C). There were also no differences in muscle fiber number or size, consistent with the normal size of gephyrin-deficient mice at P0 (Feng et al., 1998). Furthermore, skeletal muscles had a similar proportion of peripherally placed nuclei in both gephyrin-deficient (69 of 504 muscles counted; $13.7 \% ; n=4$ ) and wild-type (52 of 401 muscles 
Table 2. Spontaneous neural activity is increased for hypoglossal (XII) nerve and decreased for lumbar 5 nerve in gephyrin-deficient mice (-/-) compared with wild-type mice $(+/+)$

\begin{tabular}{|c|c|c|c|c|}
\hline & \multicolumn{2}{|l|}{ XII nerve } & \multicolumn{2}{|l|}{ L5 nerve } \\
\hline & $+/+(n=6)$ & $-/-(n=4)$ & $+/+(n=9)$ & $-/-(n=7)$ \\
\hline Burst frequency $(\mathrm{Hz})$ & $0.0285 \pm 0.0171$ & $0.0648 \pm 0.0287^{*}$ & $0.0872 \pm 0.0588$ & $0.0209 \pm 0.0065^{*}$ \\
\hline Peak burst amplitude (V) & $0.700 \pm 0.41$ & $1.30 \pm 1.05$ & $0.81 \pm 0.34$ & $1.35 \pm 0.76$ \\
\hline Burst half-width (ms) & $88.74 \pm 46.27$ & $119.29 \pm 13.52$ & $95.54 \pm 19.87$ & $103.03 \pm 22.01$ \\
\hline Burst $10-90 \%$ rise time (ms) & $99.05 \pm 47.44$ & $138.25 \pm 29.20$ & $203.55 \pm 141.78$ & $100.65 \pm 57.98$ \\
\hline Burst $10-90 \%$ decay time (ms) & $166.17 \pm 54.81$ & $262.02 \pm 79.10$ & $302.88 \pm 134.9$ & $273.82 \pm 191.01$ \\
\hline Burst area (V/ms) & $138.35 \pm 94.04$ & $356.19 \pm 131.55$ & $298.40 \pm 162.39$ & $280.01 \pm 205.71$ \\
\hline Mean nerve activity (charge/min) & $0.0732 \pm 0.0668$ & $0.3433 \pm 0.1309^{*}$ & $0.4087 \pm 0.3120$ & $0.1001 \pm 0.0795^{*}$ \\
\hline
\end{tabular}

${ }^{*} p<0.05$; Student's $t$ test.

Table 3. Glycine (100 $\mu \mathrm{M})$ or GABA ( $100 \mu \mathrm{M})$ increases lumbar 5 nerve burst frequency and decreases hypoglossal nerve burst frequency in wild-type mice; the effects of glycine on burst frequency are abolished in gephyrin-deficient mice, whereas the effects of GABA are enhanced

\begin{tabular}{|c|c|c|c|c|}
\hline & \multicolumn{2}{|l|}{ XII nerve } & \multicolumn{2}{|l|}{ L5 nerve } \\
\hline & $+1+$ & $-1-$ & $+1+$ & $-1-$ \\
\hline Glycine & $n=5$ & $n=5$ & $n=6$ & $n=8$ \\
\hline Burst frequency (\% of control) & $55.95 \pm 12.93$ & $88.95 \pm 18.14$ & $162.47 \pm 27.25$ & $104.21 \pm 15.76^{*}$ \\
\hline Peak burst amplitude (\% of control) & $122.05 \pm 20.33$ & $127.37 \pm 38.1$ & $102.26 \pm 12.63$ & $102.54 \pm 25.63$ \\
\hline Burst area (\% of control) & $90.06 \pm 13.14$ & $236.97 \pm 114.2$ & $89.79 \pm 14.61$ & $69.89 \pm 15.56$ \\
\hline GABA & $n=5$ & $n=5$ & $n=8$ & $n=6$ \\
\hline Burst frequency (\% of control) & $66.97 \pm 23.42$ & $39.48 \pm 6.37$ & $117.08 \pm 15.92$ & $159.38 \pm 18.07$ \\
\hline Peak burst amplitude (\% of control) & $228.87 \pm 146.45$ & $65.75 \pm 20.41$ & $119.17 \pm 31.92$ & $123.2 \pm 31.56$ \\
\hline Burst area (\% of control) & $100.72 \pm 35.37$ & $74.53 \pm 18.54$ & $117.61 \pm 28.52$ & $149.63 \pm 56.34$ \\
\hline
\end{tabular}

${ }^{*} p<0.05$; two-way ANOVA with Bonferroni's post hoc test.

counted; $12.9 \% ; n=4$ ) mice (Fig. $6 C$, arrows), indicating that there was no difference in the gross appearance of myotubes between gephyrin-deficient and wild-type mice.

\section{Discussion}

Our study demonstrates a role for glycinergic synapses in the development and refinement of the neuromotor system. Mice lacking gephyrin, a molecule needed for clustering of all glycine and many $\mathrm{GABA}_{\mathrm{A}}$ receptors, showed regionally distinct differences in motoneuron activity, motoneuron number, and muscle innervation. Respiratory motoneurons displayed increased motor activity, decreased motoneuron survival, restricted intramuscular axonal branching, and fewer neuromuscular synapses. In contrast, limb-innervating motoneurons displayed decreased motor activity, increased motoneuron survival, extensive axonal branching, and more neuromuscular synapses. Both GABA and glycine increased limb-innervating motoneuron activity and decreased respiratory motoneuron activity in wild-type mice, but these effects were abolished only for glycine responses in gephyrin-deficient mice. This suggests that regional differences in motor pool activity attributable to perturbed central glycinergic synaptic activity contribute to regulating the refinement of motoneuron numbers and innervation during developmental motoneuron death.

\section{Skeletal muscle activity regulates motoneuron development in gephyrin-deficient mice}

The morphological changes in lumbar motoneurons of gephyrin-deficient mice are consistent with previous pharmacological and molecular genetic studies that identify muscle activity as a key regulator of motoneuron development by demonstrating that muscle paralysis correlates with increased motoneuron survival and muscle innervation (Oppenheim et al., 1986, 1997; Landmesser, 1992; Banks et al., 2003). Our contrasting results for respiratory motoneurons are also consistent with a regulatory role of muscle activity, because electrical overstimulation of mus- cle has been found to cause increased motoneuron death (Oppenheim and Nunez, 1982). Hence, we propose that, in distinct regions of the spinal cord and brainstem, glycinergic synaptic transmission differentially affects motoneuron activity, which then regulates muscle activity through intact innervation, because target muscles and neuromuscular junctions develop normally in gephyrin-deficient mice. Our data thus link altered pattern of motor activity with changes in motoneuron survival and innervation in developing mammalian embryos.

After motoneurons make contact with their target muscles, the extent of innervation is thought to depend on nerve-evoked muscle contraction (Dahm and Landmesser, 1988, 1991; Oppenheim et al., 1997, 2000b; Banks et al., 2003; Brandon et al., 2003). In gephyrin-deficient mice, lumbar motor activity correlates with increased neuromuscular synapse numbers in hindlimb muscles, whereas the diaphragm (a primary respiratory muscle) has a reduced number of neuromuscular synapses. We conclude that central actions of glycinergic synaptic transmission on motoneuron activity ultimately influence muscle innervation by controlling muscle contraction.

Changes in motoneuron-driven muscle activity are thought to modulate motoneuron survival by two possible mechanisms. One relies on the activity-dependent production of trophic factors by the target muscle [production hypothesis (Oppenheim, 1989)], and the other proposes that the level of muscle activity regulates the ability of motoneurons to access muscle-derived trophic factors through appropriate adjustment of neuromuscular synapse numbers [access hypothesis (Oppenheim et al., 1989; Landmesser, 1992)]. Although our study was not designed to distinguish between these two mechanisms, our observations are consistent with the idea that access to target-derived trophic factors plays a role in regulating motoneuron survival, because we found motoneuron activity inversely correlates with motoneuron survival, axon branching, and neuromuscular synapse numbers in gephyrin-deficient mice. 
Changes in motoneuron activity in gephyrin-deficient mice are likely to result from impaired glycine transmission

Glycine and GABA may promote neuromotor system refinement through their excitatory actions on embryonic neurons, in contrast to their inhibitory function in the adult CNS (Singer and Berger, 2000; Ben-Ari, 2002). The response to these neurotransmitters shifts from excitatory to inhibitory during development because of changes in intracellular $\mathrm{Cl}^{-}$concentration (Ganguly et al., 2001; Ben-Ari, 2002; Hanson and Landmesser, 2003). Embryonic neurons have high intracellular $\mathrm{Cl}^{-}$concentrations (Chen et al., 1996; Singer and Berger, 2000; Ganguly et al., 2001). In this situation, $\mathrm{Cl}^{-}$efflux occurs during glycine/GABA $A_{\mathrm{A}}$ receptor activation, thereby depolarizing the neuron and evoking postsynaptic action potentials (Singer and Berger, 2000). During perinatal development, changes in potassium chloride cotransporter expression and activity lowers intracellular $\mathrm{Cl}^{-}$concentration, so that $\mathrm{GABA}_{\mathrm{A}}$ and glycine receptor activation in maturing neurons causes $\mathrm{Cl}^{-}$influx and thus membrane potential hyperpolarization (Singer and Berger, 2000; Ganguly et al., 2001). Hence, during embryonic development, glycine/GABA $\mathrm{A}_{\mathrm{A}}$ receptor activation should cause similar excitatory responses in motor activity, which may arise via direct actions on motoneurons and/or on their premotor circuitry.

Our results clarify the relative contributions of glycine and GABA neurotransmission to the changes in motoneuron activity, survival, and muscle innervation for the two motoneuron pools in gephyrindeficient mice. When applying glycine or GABA, we observed consistent changes in hypoglossal and lumbar motor nerve activity. Our findings for glycine are consistent with our observations of changed spontaneous activity for these two motoneuron pools. In wild-type hypoglossal motoneurons, there were significant decreases in burst frequency when glycine or GABA were added, but only GABA decreased burst frequency in gephyrindeficient nerves compared with control (Fig. 5D, E, dashed lines). For lumbar motor nerves, we found the opposite result, because burst frequency increased when glycine or GABA was added to wild-type preparations compared with control, but only GABA increased burst frequency in gephyrin-deficient mice compared with control (Fig. 5D,E, dashed lines). Thus, both glycine and GABA inhibit hypoglos-
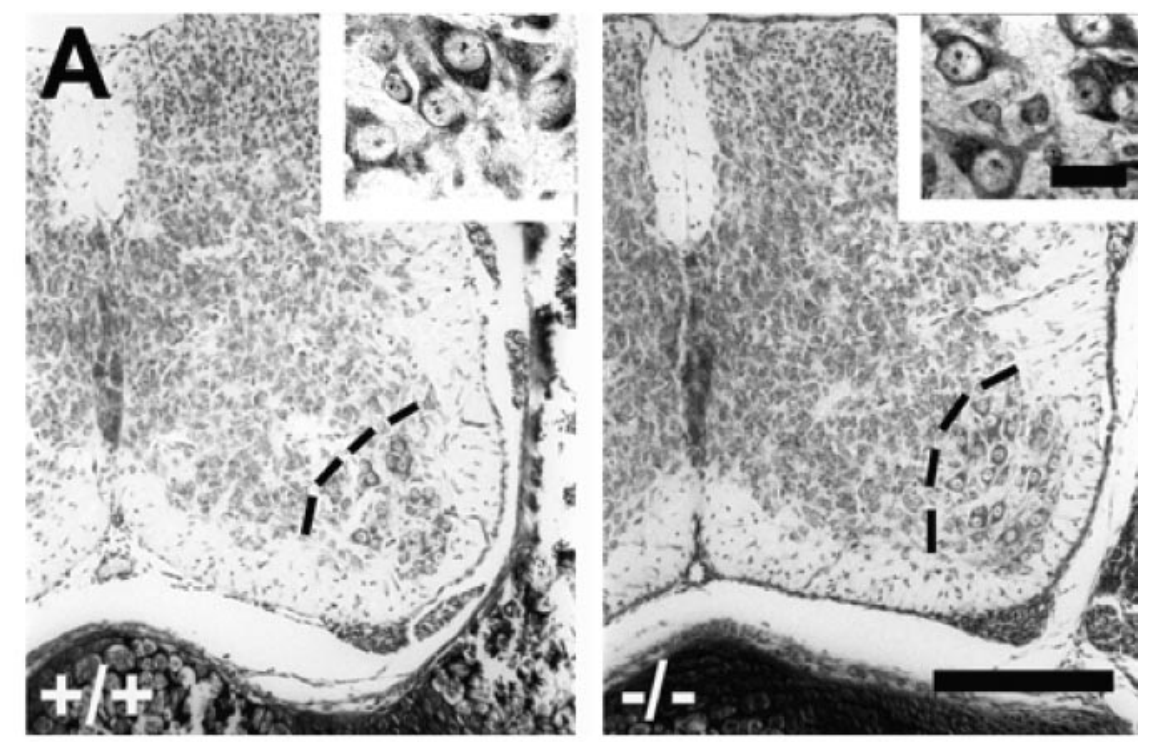

B

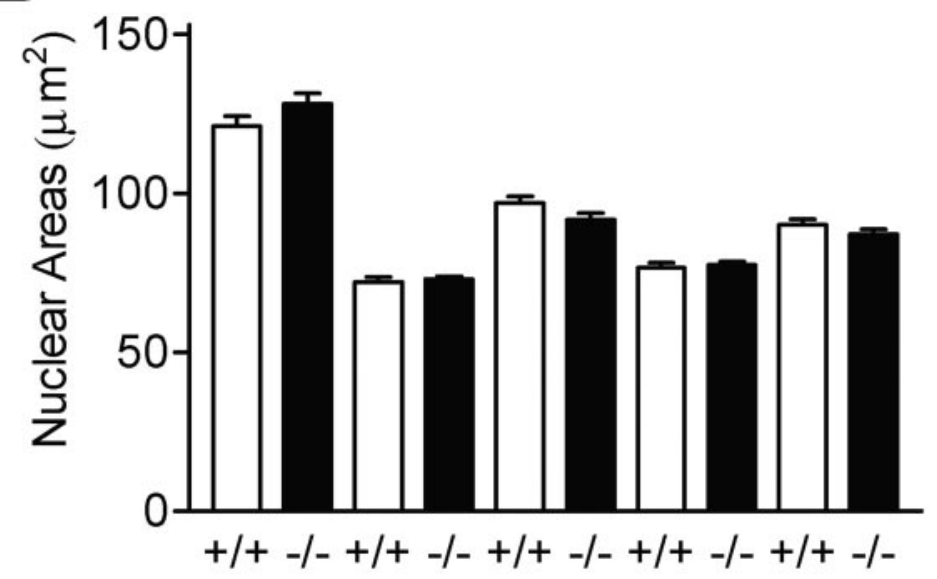

Brachial IV V VII XII
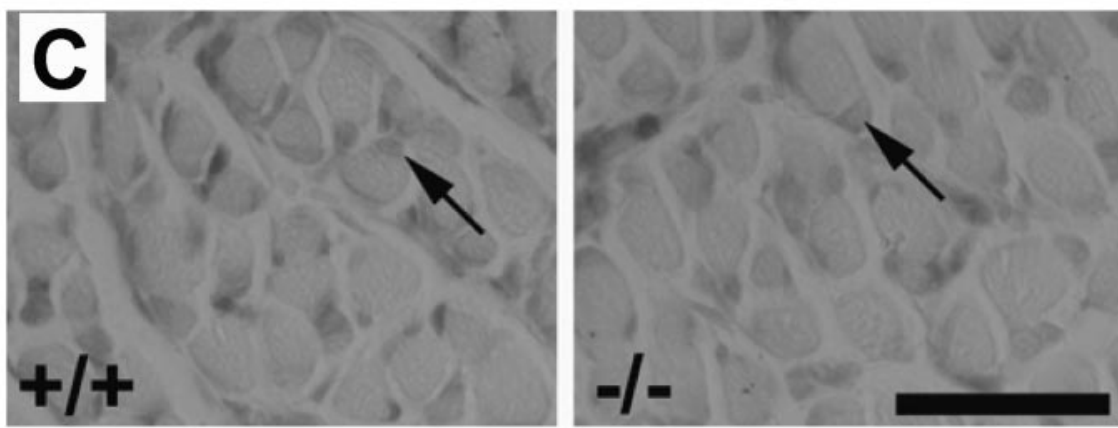

Figure 6. The morphology and differentiation of motoneurons and muscle are unaltered in gephyrin-deficient mice. $A$, Light micrographs of the lumbar spinal cords, showing the LMCs and motoneurons within gephyrin-deficient ( $-/-)$ and wild-type $(+/+)$ littermates at E18.5. Dashed lines indicate the medial border of the LMC. Insets show a higher magnification of motoneurons located within the LMC. Scale bars: $100 \mu \mathrm{m}$; insets, $20 \mu \mathrm{m}$. $B$, The motoneuron nuclear areas (mean \pm SEM) in wild-type controls ( + /+; white bars) and gephyrin-deficient mice $(-/-$; black bars) taken at E18.5 for brachial motoneurons and E15.5 for trochlear (IV), trigeminal ( V), facial (VII), and hypoglossal (XII) motor nuclei. Measurements of nuclear areas were obtained from 50 motoneurons from four litter-matched pairs and taken to be an indirect measure of motoneuron size. $C$, Transverse sections of wild-type $(+/+)$ and gephyrin-deficient $(-/-)$ skeletal muscle at $P 0$, showing no change in morphology or peripheral localization of their nuclei (arrows). Scale bar, $30 \mu \mathrm{m}$. 


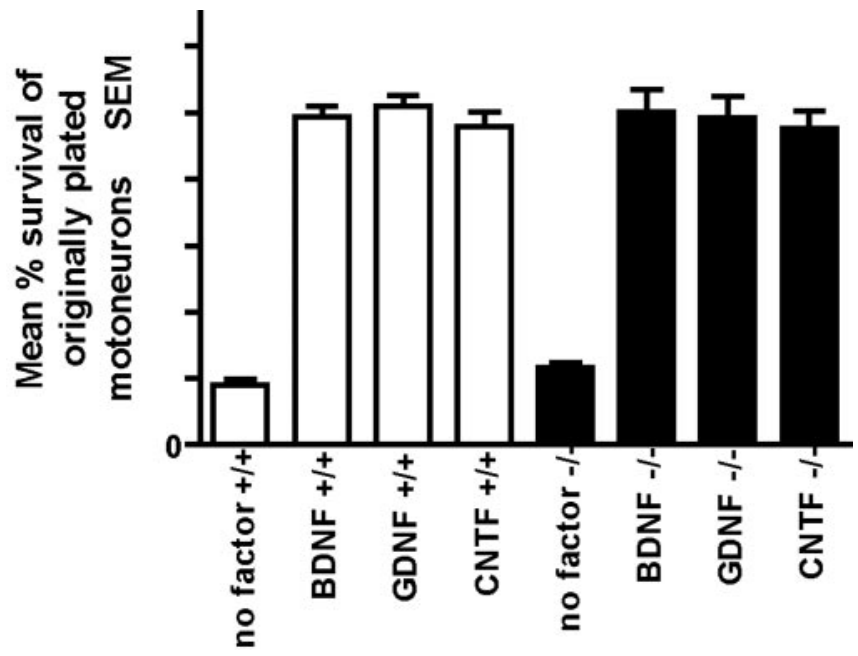

Figure 7. In vitro differentiation of motoneurons is unaltered in gephyrin-deficient mice. Shown is mean survival of motoneurons isolated from E14 wild-type $(+/+$; white bars) and gephyrin-deficient ( $-/-$; black bars) embryos after $5 \mathrm{~d}$ in culture, grown in Neurobasal medium only (no factor) or in Neurobasal medium supplemented with one of the following neurotrophic factors: BDNF, GDNF, or CNTF. There was no significant difference in the survival of motoneurons isolated from wild-type or gephyrin-deficient mice under any of these treatments.

sal nerve activity in wild-type mice, but only glycinergic inhibition is lost in the gephyrin-deficient mice, whereas both glycine and GABA excite lumbar nerve activity in wild-type mice, with only glycinergic excitation being lost in gephyrin-deficient mice. The similar responses to glycine and GABA in wild-type mice further supports the idea that the differential changes in hypoglossal and lumber motor nerve activity in gephyrin-deficient mice are likely to result from differences in the timing of $\mathrm{Cl}^{-}$dependent glycinergic transmission switching from excitation to inhibition in different premotor circuits.

Although impaired glycinergic neurotransmission makes a major contribution to altered motoneuron survival and motor activity in gephyrin-deficient mice, deficiencies in GABAergic transmission may also contribute to the phenotype, because clustering of distinct $\mathrm{GABA}_{\mathrm{A}}$ receptor subunits is significantly reduced at central synapses of gephyrin-deficient mice (Fischer et al., 2000; Rekling et al., 2000; Kneussel et al., 2001; Levi et al., 2004). GABA produced consistent changes in hypoglossal and lumbar motor nerve activity in gephyrin-deficient mice, and responses were greater than those GABA responses seen in wildtype mice. This suggests that GABA responses may be up regulated in the absence of gephyrin, possibly in response to a loss of glycinergic responses. Our experiments do not address the question of which GABA receptors $\left(\mathrm{GABA}_{\mathrm{A}}, \mathrm{GABA}_{\mathrm{B}}\right.$, and $\left.\mathrm{GABA}_{\mathrm{C}}\right)$ underlie responses in wild-type or gephyrin-deficient mice. Thus, $\mathrm{Cl}^{-}$-dependent GABAergic responses may also contribute to regulation of motor activity, and hence motoneuron PCD, in wild-type-mice and may upregulate to partially compensate for a loss of gephyrin-dependent glycine/GABA $\mathrm{A}_{\mathrm{A}}$ receptor clustering in gephyrin-deficient mice.

\section{Glycinergic synapses act to regulate motoneuron excitability through regional effects on premotor circuitry in gephyrin- deficient mice}

Changes in the frequency of rhythmic motor bursts imply effects on central pattern generation, whereas changes in motor burst parameters may be attributable to effects on presynaptic inputs to motoneurons or to direct effects on motoneuron excitability (Marder and Calabrese, 1996). We observed significant changes in burst frequencies but not in burst parameters, such as amplitude or area, for both hypoglossal and lumbar nerves in gephyrindeficient mice compared with controls. Specifically, hypoglossal nerve burst frequency increased, whereas lumbar nerve burst frequency decreased. This suggests that both glycine and GABA differentially alter activity in the respiratory and locomotor pattern generators driving hypoglossal and lumbar motor pools, respectively (Marder and Calabrese, 1996; Rekling et al., 2000). Our results indicate that glycine and GABA are inhibitory for the respiratory premotor circuit but excitatory for the locomotor premotor circuit at P0-P1 in wild-type mice.

Evidence from other studies supports this supposition. Glycine/GABA $\mathrm{A}_{\mathrm{A}}$ receptor activation increases lumbar motor burst frequency in early embryonic mouse (Hanson and Landmesser, 2003) and rat (Narayanan et al., 1971; Nishimaru et al., 1996); this response changes to decreased burst frequency only 1-2 d before birth (Nishimaru et al., 1996; Nishimaru and Kudo, 2000). In contrast, glycine/GABA $\mathrm{A}_{\mathrm{A}}$ receptor activation depresses respiratory motor frequency at earlier stages of embryonic development, from E16 onward (Ren and Greer, 2003). Our observations in wild-type mice, together with these findings, are consistent with the idea that glycine/GABA responses may switch from excitatory to inhibitory in respiratory premotor circuitry earlier than in locomotor premotor circuitry. In gephyrin-deficient mice, we found that only glycine effects on burst frequency were abolished. Thus, our experiments reveal that glycine receptordependent responses contribute to control of motor activity and hence motoneuron death and innervation.

We did not observe significant changes in motoneuron excitability, as measured by burst amplitude or charge, in either wildtype or gephyrin-deficient mice. This is in accord with other results, which indicate that direct GABA/glycine responses of motoneurons remain excitatory until after birth. For example, direct recordings from rat lumbar motoneurons have shown that GABA/glycine continue to evoke membrane depolarization up to and after birth (Wu et al., 1992; Kulik et al., 2000; Marchetti et al., 2002). Similarly, rat and mouse hypoglossal motoneurons are depolarized by GABA/glycine until postnatal ages (Ritter and Zhang, 2000; Singer and Berger, 2000; Marchetti et al., 2002). It is thus unlikely that differential effects of gephyrin deficiency on embryonic motoneuron survival and activity could be attributable to differences in GABA/glycine responses at synapses on respiratory and locomotor motoneurons.

In conclusion, we demonstrate that glycinergic responses make a vital contribution to the development of motor circuit activity, motoneuron survival, and muscle innervation during embryonic life in mammals.

\section{References}

Acsadi G, Anguelov RA, Yang H, Toth G, Thomas R, Jani A, Wang Y, Ianakova E, Mohammad S, Lewis RA, Shy ME (2002) Increased survival and function of SOD1 mice after glial-derived neurotrophic factor gene therapy. Hum Gene Ther 13:1047-1059.

Allison DW, Chervin AS, Gelfand VI, Craig AM (2000) Postsynaptic scaffolds of excitatory and inhibitory synapses in hippocampal neurons: maintenance of core components independent of actin filaments and microtubules. J Neurosci 20:4545-4554.

Arakawa Y, Sendtner M, Thoenen H (1990) Survival effect of ciliary neurotrophic factor (CNTF) on chick embryonic motoneurons in culture: comparison with other neurotrophic factors and cytokines. J Neurosci 10:3507-3515.

Ashwell KW, Watson CR (1983) The development of facial motoneurones 
in the mouse-neuronal death and the innervation of the facial muscles. J Embryol Exp Morphol 77:117-141.

Banks GB, Chau TN, Bartlett SE, Noakes PG (2001) Promotion of motoneuron survival and branching in rapsyn-deficient mice. J Comp Neurol 429:156-165.

Banks GB, Choy PT, Lavidis NA, Noakes PG (2003) Neuromuscular synapses mediate motor axon branching and motoneuron survival during the embryonic period of programmed cell death. Dev Biol 257:71-84.

Ben-Ari Y (2002) Excitatory actions of GABA during development: the nature of the nurture. Nat Rev Neurosci 3:728-739.

Bordet T, Lesbordes JC, Rouhani S, Castelnau-Ptakhine L, Schmalbruch H, Haase G, Kahn A (2001) Protective effects of cardiotrophin-1 adenoviral gene transfer on neuromuscular degeneration in transgenic ALS mice. Hum Mol Genet 10:1925-1933.

Brandon EP, Lin W, D'Amour KA, Pizzo DP, Dominguez B, Sugiura Y, Thode S, Ko CP, Thal LJ, Gage FH, Lee KF (2003) Aberrant patterning of neuromuscular synapses in choline acetyltransferase-deficient mice. J Neurosci 23:539-549.

Chen G, Trombley PQ, van den Pol AN (1996) Excitatory actions of GABA in developing rat hypothalamic neurones. J Physiol (Lond) 494:451-464.

Clarke PGH, Oppenheim RW (1995) Neuron death in vertebrate development: in vivo methods. In: Methods in cell biology (Schwartz LM, Osborne BA, eds), pp 277-321. New York: Academic.

Dahm LM, Landmesser LT (1988) The regulation of intramuscular nerve branching during normal development and following activity blockade. Dev Biol 130:621-644.

Dahm LM, Landmesser LT (1991) The regulation of synaptogenesis during normal development and following activity blockade. J Neurosci 11:238-255.

Essrich C, Lorez M, Benson JA, Fritschy JM, Luscher B (1998) Postsynaptic clustering of major GABAA receptor subtypes requires the gamma 2 subunit and gephyrin. Nat Neurosci 1:563-571.

Feng G, Tintrup H, Kirsch J, Nichol MC, Kuhse J, Betz H, Sanes JR (1998) Dual requirement for gephyrin in glycine receptor clustering and molybdoenzyme activity. Science 282:1321-1324.

Fischer F, Kneussel M, Tintrup H, Haverkamp S, Rauen T, Betz H, Wassle H (2000) Reduced synaptic clustering of GABA and glycine receptors in the retina of the gephyrin null mutant mouse. J Comp Neurol 427:634-648.

Forger NG, Prevette D, deLapeyriere O, de Bovis B, Wang S, Bartlett P, Oppenheim RW (2003) Cardiotrophin-like cytokine/cyotokine-like factor 1 is an essential trophic factor for lumbar and facial motoneurons in vivo. J Neurosci 23:8854-8858.

Ganguly K, Schinder AF, Wong ST, Poo M (2001) GABA itself promotes the developmental switch of neuronal GABAergic responses from excitation to inhibition. Cell 105:521-532.

Gautam M, Noakes PG, Mudd J, Nichol M, Chu GC, Sanes JR, Merlie JP (1995) Failure of postsynaptic specialization to develop at neuromuscular junctions of rapsyn-deficient mice. Nature 377:232-236.

Grosskreutz Y, Betz H, Kneussel M (2003) Rescue of molybdenum cofactor biosynthesis in gephyrin-deficient mice by $\mathrm{Cnx} 1$ transgene. Biochem Biophys Res Commun 301:450-455.

Hanson MG, Landmesser LT (2003) Characterization of the circuits that generate spontaneous episodes of activity in the early embryonic mouse spinal cord. J Neurosci 23:587-600.

Herroma JH, Plomp JJ, Roubos EW, Verhage M (2003) Development of the mouse neuromuscular junction in the absence of regulated secretion. Neuroscience 120:733-744.

Hughes RA, Sendtner M, Thoenen H (1993) Members of several gene families influence survival of rat motoneurons in vitro and in vivo. J Neurosci Res 36:663-671.

Kirsch J, Betz H (1993) Widespread expression of gephyrin, a putative glycine receptor-tubulin linker protein, in rat brain. Brain Res 621:301-310.

Kneussel M, Brandstatter JH, Laube B, Stahl S, Muller U, Betz H (1999) Loss of postsynaptic $\mathrm{GABA}_{\mathrm{A}}$ receptor clustering in gephyrin-deficient mice. J Neurosci 19:9289-9297.

Kneussel M, Brandstatter JH, Gasnier B, Feng G, Sanes JR, Betz H (2001) Gephyrin-independent clustering of postsynaptic GABA(A) receptor subtypes. Mol Cell Neurosci 17:973-982.

Kopriwa BM (1984) Block-staining tissues with potassium ferrocyanide reduced osmium tetroxide and lead aspartate for electron microscopic radioautography. J Histochem Cytochem 32:552-554.
Kriegstein AR, Owens DF (2001) GABA may act as a self-limiting trophic factor at developing synapses. Sci STKE 95:PE1.

Kulik A, Nishimaru H, Ballanyi K (2000) Role of bicarbonate and chloride in GABA- and glycine-induced depolarization and $\left[\mathrm{Ca}^{2+}\right]_{\mathrm{i}}$ rise in fetal rat motoneurons in situ. J Neurosci 20:7905-7913.

Lance-Jones C (1982) Motoneuron cell death in the developing lumbar spinal cord of the mouse. Brain Res 256:473-479.

Landmesser L (1992) The relationship of intramuscular nerve branching and synaptogenesis to motoneuron survival. J Neurobiol 23:1131-1139.

Levi S, Logan SL, Tovar KR, Craig AM (2004) Gephyrin is critical for glycine receptor clustering but not for the formation of functional GABAergic synapses in hippocampal neurons. J Neurosci 24:207-217.

Lu YY, Wang LJ, Muramatsu S, Ikeguchi K, Fujimoto K, Okada T, Mizukami H, Matsushita T, Hanazono Y, Kume A, Nagatsu T, Ozawa K, Nakano I (2003) Intramuscular injection of AVV-GDNF results in sustained expression of transgenic GDNF, and its delivery to spinal motoneurons by retrograde transport. Neurosci Res 45:33-40.

Marchetti C, Pagnotta S, Donato R, Nistri A (2002) Inhibition of spinal or hypoglossal motoneurons of the newborn rant by glycine or GABA. Eur J Neurosci 15:975-983.

Marder E, Calabrese RL (1996) Principles of rhythmic motor pattern generation. Physiol Rev 76:687-717.

Masiakowski P, Liu HX, Radziejewski C, Lottspeich F, Oberthuer W, Wong V, Lindsay RM, Furth ME, Panayotatos N (1991) Recombinant human and rat ciliary neurotrophic factors. J Neurochem 57:1003-1012.

Metzger F, Wiese S, Sendtner M (1998) Effect of glutamate on dendritic growth in embryonic rat motoneurons. J Neurosci 18:1735-1742.

Millecamps S, Nicolle D, Ceballos-Picot I, Mallet J, Barkats M (2001) Synaptic sprouting increases the uptake capacities of motoneurons in amyotrophic lateral sclerosis mice. Proc Natl Acad Sci USA 98:7582-7587.

Millecamps S, Mallet J, Barkats M (2002) Adenoviral retrograde gene transfer in motoneurons is greatly enhanced by prior intramuscular inoculation with botulinum toxin. Hum Gene Ther 13:225-232.

Narayanan CH, Fox MW, Hamburger V (1971) Prenatal development of spontaneous and evoked activity in the rat (Rattus norvegicus albinus). Behaviour 40:100-134.

Nishimaru H, Kudo N (2000) Formation of the central pattern generator for locomotion in the rat and mouse. Brain Res Bull 53:661-669.

Nishimaru H, Iizuka M, Ozaki S, Kudo N (1996) Spontaneous motoneuronal activity mediated by glycine and GABA in the spinal cord of rat fetuses in vitro. J Physiol (Lond) 497:131-143.

Noakes PG, Bennett MR, Davey DF (1983) Growth of segmental nerves to the developing rat diaphragm: absence of pioneer axons. J Comp Neurol 218:365-377.

Oppenheim RW (1989) The neurotrophic theory and naturally occurring motoneuron death. Trends Neurosci 12:252-255.

Oppenheim RW (1991) Cell death during development of the nervous system. Annu Rev Neurosci 14:453-501.

Oppenheim RW, Nunez R (1982) Electrical stimulation of hindlimb increases neuronal cell death in chick embryo. Nature 295:57-59.

Oppenheim RW, Rose LL, Stokes BT (1982) Cell death of motoneurons in the chick embryo spinal cord. VII. The survival of brachial motoneurons in dystrophic chickens. Exp Neurol 78:112-120.

Oppenheim RW, Houenou L, Pincon-Raymond M, Powell JA, Rieger F, Standish LJ (1986) The development of motoneurons in the embryonic spinal cord of the mouse mutant, muscular dysgenesis ( $m d g / m d g)$ : survival, morphology, and biochemical differentiation. Dev Biol 114:426-436.

Oppenheim RW, Bursztajn S, Prevette D (1989) Cell death of motoneurons in the chick embryo spinal cord. XI. Acetylcholine receptors and synaptogenesis in skeletal muscle following the reduction of motoneuron death by neuromuscular blockade. Development 107:331-341.

Oppenheim RW, Prevette D, Houenou LJ, Pincon-Raymond M, Dimitriadou V, Donevan A, M OD, Wenner P, McKemy DD, Allen PD (1997) Neuromuscular development in the avian paralytic mutant crooked neck dwarf $(\mathrm{cn} / \mathrm{cn})$ : further evidence for the role of neuromuscular activity in motoneuron survival. J Comp Neurol 381:353-372.

Oppenheim RW, Houenou LJ, Parsadanian AS, Prevette D, Snider WD, Shen L (2000a) Glial cell line-derived neurotrophic factor and developing mammalian motoneurons: regulation of programmed cell death among motoneuron subtypes. J Neurosci 20:5001-5011.

Oppenheim RW, Prevette D, D'Costa A, Wang S, Houenou LJ, McIntosh JM (2000b) Reduction of neuromuscular activity is required for the rescue of 
motoneurons from naturally occurring cell death by nicotinic-blocking agents. J Neurosci 20:6117-6124.

Oppenheim RW, Claldero J, Cuitat D, Esquerda J, Ayala V, Prevette D, Wang S (2003) Rescue of developing spinal motoneurons from programmed cell death by the GABAA agonist muscimol acts by blockade of neuromuscular activity and increased intramuscular nerve branching. Mol Cell Neurosci 22:331-343.

Owens DF, Kriegstein AR (2002) Is there more to GABA than synaptic inhibition? Nat Rev Neurosci 3:715-727.

Prior P, Schmitt B, Grenningloh G, Pribilla I, Multhaup G, Beyreuther K, Maulet Y, Werner P, Langosch D, Kirsch J, Betz H (1992) Primary structure and alternative splice variants of gephyrin, a putative glycine receptor-tubulin linker protein. Neuron 8:1161-1170.

Rekling JC, Funk GD, Bayliss DA, Dong XW, Feldman JL (2000) Synaptic control of motoneuronal excitability. Physiol Rev 80:767-852.

Ren J, Greer JJ (2003) Ontogeny of rhythmic motor patterns generated in the embryonic rat spinal cord. J Neurophysiol 89:1187-1195.

Reynolds ES (1963) The use of lead citrate at high $\mathrm{pH}$ as an electron opaque stain in EM. J Cell Biol 17:208-212.

Ritter B, Zhang W (2000) Early postnatal maturation of GABA(A)mediated inhibition in the brainstem respiratory rhythm-generating network of the mouse. Eu J Neurosci 12:2975-2984.

Sanes JR, Lichtman JW (1999) Development of the vertebrate neuromuscular junction. Annu Rev Neurosci 22:389-442.

Sanes JR, Apel ED, Burgess RW, Emerson RB, Feng G, Gautam M, Glass D, Grady RM, Krejci E, Lichtman JW, Lu JT, Massoulie J, Miner JH, Moscoso LM, Nguyen Q, Nichol M, Noakes PG, Patton BL, Son YJ, Yancopoulos GD, et al. (1998) Development of the neuromuscular junction: genetic analysis in mice. J Physiol (Paris) 92:167-172.

Schmitt B, Knaus P, Becker CM, Betz H (1987) The Mr 93,000 polypeptide of the postsynaptic glycine receptor complex is a peripheral membrane protein. Biochemistry 26:805-811.

Sendtner M, Pei G, Beck M, Schweizer U, Wiese S (2000) Developmental motoneuron cell death and neurotrophic factors. Cell Tissue Res 301:71-84.

Singer JH, Berger AJ (2000) Development of inhibitory synaptic transmission to motoneurons. Brain Res Bull 53:553-560.

Smith JC, Feldman JL (1987) In vitro brainstem-spinal cord preparations for study of motor systems for mammalian respiration and locomotion. J Neurosci Methods 21:321-333.

Suzue T (1984) Respiratory rhythm generation in the in vitro brain stemspinal cord preparation of the neonatal rat. J Physiol (Lond) 354:173-183.

Tang J, Landmesser L (1993) Reduction of intramuscular nerve branching and synaptogenesis is correlated with decreased motoneuron survival. J Neurosci 13:3095-3103.

Terrado J, Burgess RW, DeChiara T, Yancopoulos G, Sanes JR, Kato AC (2001) Motoneuron survival is enhanced in the absence of neuromuscular junction formation in embryos. J Neurosci 21:3144-3150.

Verhage M, Maia AS, Plomp JJ, Brussaard AB, Heeroma JH, Vermeer H, Toonen RF, Hammer RE, van den Berg TK, Missler M, Geuze HJ, Sudhof TC (2000) Synaptic assembly of the brain in the absence of neurotransmitter secretion. Science 287:864-869.

Wang LJ, Lu YY, Muramatsu S, Ikeguchi K, Fujimoto K, Okada T, Mizukami H, Matsushita T, Hanazono Y, Kume A, Nagatsu T (2002) Neuroprotective effects of glial cell line-derived neurotrophic factor mediated by an adeno-associated virus vector in a transgenic animal model of amyotrophic lateral sclerosis. J Neurosci 22:6920-6928.

Wu WL, Ziskind-Conhaim L, Sweet MA (1992) Early development of glycine- and GABA-mediated synapses in rat spinal cord. J Neurosci 12: 3935-3945. 